East African Medical Journal Vol. 80 No. 4 April 2003

MALE CONDOM USE IN TANZANIA: RESULTS FROM A NATIONAL SURVEY

S.H. Kapiga, MD. Sc.D, Department of Population and International Health, Harvard School of Public Health, Boston, M.A, 02115 USA and J.L.P. Lugalla, PhD, Department of Sociology and Anthropology, University of New Hampshire, Durham, NH, USA

Request for reprints to: Dr. S.H. Kapiga, Department of Population and International Health, Harvard School of Public Health, 665 Huntington Avenue, Bldg I-1106A, Boston, M.A.02115 USA

\title{
MALE CONDOM USE IN TANZANIA: RESULTS FROM A NATIONAL SURVEY
}

\author{
S.H. KAPIGA and J.L.P. LUGALLA
}

\begin{abstract}
Objective: To determine factors associated with male condom use in Tanzania.

Methods: Data from the 1996 Tanzania Demographic and Health Survey (TDHS) was used. In this survey, a national representative sample of sexually active men $(N=1898)$ and women $(\mathrm{N}=7027)$ were interviewed to obtain information about potential predictors of sexual practices and condom use.

Results: Two hundred and ninety $(4.1 \%)$ women and $288(15.2 \%)$ men had used condoms during their last sexual encounter. Men aged 20-24 years and women aged 15-19 years reported the highest rate of condom use. In both men and women, condom use increased with increasing level of education. Residents of large urban centers were more likely to have used condoms among both women [adjusted $\mathrm{OR}=1.8,95 \% \mathrm{Cl}=\mathbf{1 . 2}-2.8$ ] and men (adjusted $\mathrm{O}=\mathbf{2 . 0}$, $95 \% \mathrm{Cl}=1.3-3.1)$. Condom use was significantly increased among women (adjusted $\mathrm{OR}=6.2$, 95\% $\mathrm{Cl}=4.4-8.8$ ) and men [adjusted $\mathrm{OR}-5.9,95 \% \mathrm{Cl}=3.2-8.8$ ) practising high-risk sexual behaviour. Similarly, condom use was significantly increased among men who were never married and in those who had ever tested for AIDS.

Conclusions: Condom promotion activities have been less successful in Tanzania. Additional efforts to increase condom acceptability and use are urgently needed.
\end{abstract}

\section{INTRODUCTION}

Condoms are known to reduce the risk of exposure to the HIV virus during sexual intercourse, leading to decreased transmission of HIV infection(1). Hence, condom promotion is one of the key strategies adopted by public health programmes aimed at reducing the rate of spread of the HIV epidemic(2). Consistent condom use has been shown to be highly effective in preventing sexual transmission of HIV/ AIDS $(1,3,4)$. In populations at the highest risk of HIV infection, significant reduction of HIV transmission has been reported even when condoms are used less consistently $(4,5)$. Condoms may also indirectly slow the spread of HIV by preventing the transmission of other sexually transmitted diseases (STDs) that act as co-factors for HIV transmission(6). Hence, the overall effect of condom use in prevention of HIV transmission may be significantly higher in populations where both STDs and HIV infections are prevalent(2).

HIV/AIDS, is a major public health problem in Tanzania. By the end of 1999, the number of people infected with HIV was estimated to be more than 1.7 million (7), and a large number of new HIV infections continue to occur in most parts of the country (8-10). In 1987, the Tanzanian government established the National AIDS Control Programme (NACP) to implement and coordinate HIV/ AIDS prevention activities. In the absence of a vaccine or cure for AIDS, promotion of safer sexual practices and condom use has been the main strategy adopted by the NACP. Specific activities developed and implemented by NACP include a public information campaign to increase general awareness about HIV/AIDS and the health benefits of condoms. With support of non-governmental organisations, the NACP initiated a condom social marketing programme in 1993. This programme was designed to develop and expand the local condom distribution network, and improve condom availability and accessibility.

Several studies have reported relatively low condom use in Tanzania $(8,11,12)$, suggesting that the ongoing condom promotion efforts have been less successful. However, most of these studies were conducted in limited geographical areas and may not provide a reliable estimate of condom use at a national level. Information about sexual practices and condom use was collected from a national sample in the 1991/92 and 1996 Tanzania Demographic and Health Surveys (TDHS)(13,14).Results from these surveys provide valuable information that can be used to assess the impact of ongoing efforts to promote safer sexual practices and the use of condoms in Tanzania. In this report, we present results from the analysis we conducted to determine the level and determinants of condom use among sexually active men and women who participated in the 1996 TDHS. In this paper, we use the word condom to refer to male condoms only. 


\section{MATERIALS AND METHODS}

Survey organisation and sampling: The TDHS was conducted as part of the worldwide Demographic and Health Surveys (DHS) programme developed by Macro International Inc. The detailed methods used in this survey have been described elsewhere (14), and will be reviewed here briefly. A national representative sample for the 1996 TDHS was obtained by multistage cluster sampling using the 1988 population census enumeration areas (EA) as sampling units. Three stage sampling scheme was adopted. In the first stage, wards/branches were systematically selected by using a probability proportional sampling. During the second stage, two EA in each selected rural ward/branch and one EA in each selected urban ward/branch were randomly selected. Overall, 262 EA were selected in the rural areas and 95 in urban areas. In each selected EA, a list of households was prepared shortly before the commencement of data collection.

Table 1

Condom use among sexually active women by selected socio-demographic characteristics, Tanzania Demographic and Health Survey, 1996

\begin{tabular}{|c|c|c|c|c|}
\hline \multirow[t]{2}{*}{ Variable } & \multicolumn{2}{|c|}{$\begin{array}{l}\text { Married or cohabiting women } \\
\qquad(\mathrm{N}=5387)\end{array}$} & \multicolumn{2}{|c|}{$\begin{array}{l}\text { Women reporting to } \\
\text { have regular or non- } \\
\text { regular partners }(\mathrm{N}=1234)\end{array}$} \\
\hline & $\begin{array}{l}\text { No. in each } \\
\text { category* }\end{array}$ & $\begin{array}{l}\% \text { used condom } \\
\text { with husband }\end{array}$ & $\begin{array}{l}\text { No. in each } \\
\text { category* }\end{array}$ & $\begin{array}{l}\% \text { used condom } \\
\text { with partner }\end{array}$ \\
\hline \multicolumn{5}{|l|}{ Age (completed years) } \\
\hline $15-19$ & 400 & 1.5 & 325 & 16.3 \\
\hline $20-24$ & 1124 & 2.5 & 320 & 20.3 \\
\hline $25-29$ & 1153 & 2.3 & 209 & 15.3 \\
\hline $30-34$ & 963 & 1.7 & 144 & 13.2 \\
\hline $35-39$ & 750 & 0.8 & 122 & 13.1 \\
\hline$>40$ & 997 & 1.2 & 114 & 6.1 \\
\hline \multicolumn{5}{|l|}{ Education } \\
\hline No education & 1780 & 0.5 & 252 & 5.6 \\
\hline Incomplete primary & 925 & 1.4 & 249 & 14.5 \\
\hline Complete primary & 2412 & 2.5 & 644 & 17.7 \\
\hline Secondary and above & 270 & 4.1 & 89 & 31.5 \\
\hline \multicolumn{5}{|l|}{ Religion } \\
\hline Moslem & 2159 & 2.2 & 515 & 17.7 \\
\hline Catholic & 1532 & 1.6 & 400 & 14.5 \\
\hline Protestant & 1138 & 1.8 & 239 & 16.7 \\
\hline None/other & 542 & 0.6 & 78 & 3.8 \\
\hline \multicolumn{5}{|l|}{ Place of residence } \\
\hline Capital, large city & 399 & 5.8 & 154 & 33.8 \\
\hline Small city & 272 & 2.6 & 67 & 20.9 \\
\hline Town & 569 & 1.8 & 202 & 21.3 \\
\hline Rural areas & 4147 & 1.3 & 811 & 10.2 \\
\hline \multicolumn{5}{|l|}{ Marital status } \\
\hline Never married & - & - & 555 & 15.7 \\
\hline Married & 4772 & 1.6 & 233 & 15.5 \\
\hline Living together & 615 & 2.8 & 80 & 21.3 \\
\hline Widowed divorced/separated & - & - & 366 & 14.2 \\
\hline \multicolumn{5}{|l|}{ Nature of marriage $\mathbf{a}^{\mathbf{a}}$} \\
\hline Monogamous & 3862 & 1.9 & 198 & 20.2 \\
\hline Polygamous & 1400 & 1.0 & 94 & 11.7 \\
\hline Don't know & 89 & 4.5 & 17 & 11.8 \\
\hline \multicolumn{5}{|l|}{ Husband lives in house $\mathrm{a}^{\mathbf{a}}$} \\
\hline Living with her & 4808 & 1.5 & 259 & 16.2 \\
\hline Staying elsewhere & 553 & 3.8 & 51 & 21.6 \\
\hline
\end{tabular}

*Due to missing data, the numbers shown in each category may not add-up to the total numbers shown.

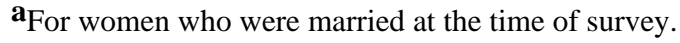


The household list was used in the third stage of sampling to select 30 households in each rural EA and 20 in urban EA. In each selected household, all women aged 15-49 years were interviewed; while in every fourth household (except in six regions where it was every second household), men aged 15-59 years were also interviewed. Interviews were conducted in a private location in the household compound by interviewers of the same sex. During the interviews, information about sociodemographic characteristics, sexual practices, condom use, contraceptive use, maternal and child health indicators, and knowledge and attitudes regarding AIDS were collected. The Tanzania Bureau Of Statistics in collaboration with the Ministry of Health conducted the survey.

Statistical analyses: All sexually active respondents were asked whether they had used condoms with their spouse and/or other sexual partners during their last sexual encounter.
We defined regular partner to be someone, other than their spouse, with whom they had a sexual relationship for at least one year. Non-regular partners were defined as partners other than spouse/regular partners with whom they had a sexual relationship for less than one year. In the analysis, we created two variables related to condom use with spouse, and regular or non-regular partners. These variables were used to describe condom use patterns within and outside of marriage. Due to a small number of respondents who had used condoms with their spouse, we generated a single variable summarising condom use with any partner and used this as our main outcome variable. Subjects were classified as condom users if they reported to have used condoms with their spouse and/or other partners during their last sexual encounter.

Analyses were performed by using SPSS statistical software (SPSS inc., Chicago, Illinois, USA). Most independent variables were recorded to create dummy variables and the

Table 2

Condom use among sexually active men by selected socio-demographic characteristics, Tanzania Demographic and Health Survey, 1996

\begin{tabular}{|c|c|c|c|c|}
\hline \multirow[t]{2}{*}{$\begin{array}{l}\text { Regular } \\
\text { variables }\end{array}$} & \multicolumn{2}{|c|}{$\begin{array}{l}\text { Married or cohabiting men } \\
\qquad(\mathrm{N}=1257)\end{array}$} & \multicolumn{2}{|c|}{$\begin{array}{c}\text { Men reporting to have } \\
\text { or non-regular partner }(\mathrm{N}=696)\end{array}$} \\
\hline & $\begin{array}{l}\text { No. in each } \\
\text { category* }\end{array}$ & $\begin{array}{l}\% \text { used condom } \\
\text { with spouse }\end{array}$ & $\begin{array}{l}\text { No. in each } \\
\text { category* }\end{array}$ & $\begin{array}{l}\% \text { used condom } \\
\text { with partner }\end{array}$ \\
\hline \multicolumn{5}{|l|}{ Age (completed years) } \\
\hline $15-19$ & 7 & 0.0 & 139 & 25.9 \\
\hline $20-24$ & 87 & 6.9 & 195 & 43.6 \\
\hline $25-29$ & 186 & 5.4 & 120 & 45.8 \\
\hline $30-34$ & 222 & 6.3 & 73 & 42.5 \\
\hline $35-39$ & 225 & 4.4 & 62 & 40.3 \\
\hline $40-44$ & 200 & 1.5 & 50 & 18.0 \\
\hline$\leq 45$ & 330 & 0.9 & 57 & 15.8 \\
\hline \multicolumn{5}{|l|}{ Education } \\
\hline No education & 203 & 3.0 & 59 & 15.3 \\
\hline Incomplete primary & 330 & 1.2 & 153 & 19.0 \\
\hline Complete primary & 590 & 4.7 & 391 & 40.9 \\
\hline Secondary and above & 134 & 6.0 & 93 & 55.9 \\
\hline \multicolumn{5}{|l|}{ Religion } \\
\hline Moslem & 448 & 5.1 & 301 & 34.6 \\
\hline Catholic & 399 & 2.3 & 207 & 39.1 \\
\hline Protestant & 267 & 4.5 & 132 & 43.9 \\
\hline None/other & 137 & 1.5 & 53 & 11.3 \\
\hline \multicolumn{5}{|l|}{ Place of residence } \\
\hline Capital, large city & 130 & 10.0 & 129 & 55.0 \\
\hline Small city & 54 & 5.6 & 29 & 41.4 \\
\hline Town & 115 & 6.1 & 69 & 34.8 \\
\hline Rural areas & 958 & 2.4 & 469 & 30.5 \\
\hline \multicolumn{5}{|l|}{ Marital status } \\
\hline Never married & - & - & 348 & 40.2 \\
\hline Married & 1151 & 3.4 & 229 & 33.6 \\
\hline Living together & 106 & 6.6 & 49 & 24.5 \\
\hline Widowed/divorced/separated & - & - & 69 & 30.4 \\
\hline \multicolumn{5}{|l|}{ Nature of marriage } \\
\hline Monogamous & 1075 & 4.0 & 251 & 33.1 \\
\hline Polygamous & 170 & 1.8 & 24 & 20.8 \\
\hline
\end{tabular}

*Due to missing data, the numbers shown in each category may not add-up to the total numbers shown.

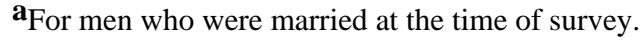


results are presented as proportions. To assess the association between condom use and sexual behaviour, we generated a single variable to identify respondents engaged in high-risk sexual behaviour. Respondents were classified to have practiced high-risk sexual behaviour if they were married or cohabiting, and had other regular or non-regular sexual partners; or if they were unmarried and had non-regular partners or more than one regular partners. We summarised the association between outcome variable and independent variables by using age-adjusted odds ratios and $95 \%$ confidence limits. To adjust for multiple predictors simultaneously, multivariate analyses were performed using logistic regression models (15). Variables were entered into the models based on the level of significance in univariate analyses $(\mathrm{p}<0.10)$. We performed separate analyses for men and women.

\section{RESULTS}

Out of 8,900 households sampled in the 1996 TDHS, interviews were conducted in 7,969 (97.9\%) households. In these households, 8,120 (95.5\%) women and 2,256 $(84.9 \%)$ men who were eligible to participate in this survey were interviewed. Among those interviewed, 7,027 $(86.5 \%)$ women and $1,898(84.1 \%)$ men reported to be sexually active. Most sexually active respondents were less than 35 years of age and had completed seven years of primary education. About $68 \%$ of women and $61 \%$ of men were married and most women $(74.5 \%)$ and men $(72.3 \%)$ resided in rural areas.

Most respondents (64\%) had their last sexual contact during the four weeks preceding the survey. Among those married, 94/5387 (1.7\%) women and 46/1257 (3.7\%) men, used condoms during their last sexual encounter with their spouse, while 192/1234 (15.6\%) women and 250/ $696(35.9 \%)$ men used condoms during their last sexual encounter with regular or non-regular partners. In Tables 1 and 2, we present the distribution of condom use with spouse and other sexual partners by selected sociodemographic characteristics. Among both women and men, use of condoms during the last sexual encounter with spouse and other male partners increased with increasing level of education. Condom use was relatively low among respondents in the older age categories. Respondents who were cohabiting and residents of capital or large towns were more likely to have used condoms with their partners.

Overall, 290/7027 (4.1\%) women and 288/1898 $(15.2 \%)$ men reported to have used condoms during their last sexual encounter with spouse and other regular or nonregular sexual partners. In Tables 3 and 4, the associations between selected predictors and condom use during the last sexual encounter is presented. Condom use decreased with increasing age among both men and women (p-value, test for linear trend $<0.0001)$. Level of education was positively associated with condom use, with respondents having at least secondary education being more likely to use condoms among both women (age adjusted odds ratio $(\mathrm{OR}=7.7,95 \%$ confidence interval $(\mathrm{Cl}=4.5-13.1)$ and men [age adjusted $\mathrm{OR}=4.8,95 \% \mathrm{Cl}: 2.6-9.0]$. Among ever- married women, we also observed increased condom use with the increasing level of education of their spouse.

Compared to residents of rural areas, respondents living in capital or large towns were significantly more likely to use condoms among both women (age-adjusted $\mathrm{OR}=4.9$, 95\% $\mathrm{Cl}=3.6-6.6$ ) and men (age-adjusted $\mathrm{OR}=3.3,95 \% \mathrm{CI}=2.4-$ 4.6). Married respondents, were significantly less likely to use condoms than those who were unmarried. Among married women, condom use was significantly increased among women not living together with their spouse. A husband's age was not significantly associated with condom use among married women (data not shown). About $21 \%$ of women and $9 \%$ of men were living in households headed by women. Respondents living in women-headed households had increased condom use, although this was only significant among women (age-adjusted $\mathrm{OR}=2.6,95 \% \mathrm{Cl}=2.1-3.4$ ). At the time of the survey, only $14.4 \%$ of women were using modern contraceptive methods. Women using traditional or modern contraceptive methods were significantly more likely to have used condoms than women not using any of these methods.

Although HIV/AIDS knowledge was relatively high in this population, only $42 \%$ of women and $57 \%$ of men spontaneously mentioned condom use as HIV/AIDS preventive measure. Respondents who spontaneously mentioned condom use as AIDS preventive measure were significantly more likely to have used condoms among women (age-adjusted $\mathrm{OR}=2.3 .95 \% \mathrm{Cl}=1.5-3.4$ ) and men [age-adjusted $\mathrm{OR}=3.1,95 \% \mathrm{Cl}=1.7-5.6]$. About $6 \%$ of women and $4 \%$ of men had a member of their household with AIDS or who has died of AIDS. Having a member of household with AIDS or died of AIDS was associated with significantly increased condom use among women. Although only $4.8 \%$ of women and $13.5 \%$ of men had tested for HIV, more than $70 \%$ of subjects interviewed wanted to be tested to know their HIV status. Condom use was significantly increased among women (age-adjusted OR 2.9, 95\% Cl=2.0-4.2) and men [age-adjusted $\mathrm{OR}=2.3$, $95 \% \mathrm{Cl}=1.6-3.2]$ who had undergone HIV testing.

Only $26.7 \%$ of women and $38.6 \%$ of men thought that they were not at risk of getting HIV/AIDS. In both women and men, condom use was relatively increased among respondents who perceived themselves at increased risk of HIV/AIDS, although the increase was not significant among those who thought they were at greatest risk of HIV/AIDS (data not shown). Although most women $(68.7 \%)$ and men $(79.2 \%)$ reported to have changed their sexual behaviour due to HIV/AIDS, only $3.5 \%$ of women and $16.2 \%$ of men reported to have increased using condoms. As expected, the majority of both women and men who reported to have increased condom use in response to HIV/AIDS had used condoms during their last sexual encounter. We also observed increased condom use among respondents who said to have changed their sexual behaviour in response to HIV/AIDS among both women [age-adjusted $\mathrm{OR}=3.5,95 \% \mathrm{Cl}=2.1-5.7$ ] and men [age-adjusted $\mathrm{OR}=1.6,95 \% \mathrm{Cl}=1.0-2.7]$. 
Table 3

Predictors of condom use during the last sexual encounter among sexually active women (N=7027), Tanzania Demographic and Health Survey, 1996

\begin{tabular}{|c|c|c|c|}
\hline & $\begin{array}{c}\text { No. }(\%) \text { in } \\
\text { each category* }\end{array}$ & $\begin{array}{c}\% \text { used condom } \\
\text { during last sexual } \\
\text { encounter }\end{array}$ & $\begin{array}{l}\text { Age-adjusted } \\
\text { OR }(95 \% \mathrm{Cl})\end{array}$ \\
\hline \multicolumn{4}{|c|}{ SOCIO-DEMOGRAPHIC CHARACTERISTIC } \\
\hline \multicolumn{4}{|c|}{ Age (completed years) } \\
\hline $15-19$ & $835(11.9)$ & 7.1 & 1.0 \\
\hline $20-24$ & $1542(21.9)$ & 6.2 & $0.9(0.6-1.2)$ \\
\hline $25-29$ & 1385 (19.7) & 4.3 & $0.6(0.4-0.9)$ \\
\hline $30-34$ & $1126(16.0)$ & 3.0 & $0.4(03-0.6)$ \\
\hline $35-39$ & $891(12.7)$ & 2.6 & $0.4(0.2-0.6)$ \\
\hline$\geq 40$ & $1248(17.8)$ & 1.5 & $0.2(0.1-0.3)$ \\
\hline $\mathrm{p}$-value, test for trend & & & $\mathrm{p}<0.0001$ \\
\hline \multicolumn{4}{|l|}{ Education } \\
\hline No education & $2129(30.3)$ & 1.1 & 1.0 \\
\hline Incomplete primary & $1245(17.7)$ & 3.9 & $3.4(2.0-5.5)$ \\
\hline Complete primary & $3242(46.1)$ & 5.5 & $4.1(2.6-6.4)$ \\
\hline Secondary and above & $411(5.8)$ & 9.5 & $7.7(4.5-13.1)$ \\
\hline p-value, test for trend & & & $\mathrm{p}<0.0001$ \\
\hline \multicolumn{4}{|l|}{ Place of residence } \\
\hline Capital, large city & $579(8.2)$ & 12.8 & $4.9(3.6-6.6)$ \\
\hline Small city & $386(5.5)$ & 5.7 & $2.1(1.3-3.4)$ \\
\hline Town & 824(11.7) & 6.6 & $2.5(1.8-3.4)$ \\
\hline Rural areas & $5238(74.5)$ & 2.7 & 1.0 \\
\hline \multicolumn{4}{|l|}{ Marital status } \\
\hline Never married & $825(11.7)$ & 11.0 & $3.6(2.6-5.0)$ \\
\hline Married & $4772(67.9)$ & 2.3 & 1.0 \\
\hline Living together & $615(8.8)$ & 5.5 & $2.3(1.6-3.4)$ \\
\hline Widowed/divorced/separated & $814(11.6)$ & 6.5 & $3.2(2.3-4.5)$ \\
\hline \multicolumn{4}{|l|}{ Husband lives in house $\mathbf{a}^{\mathbf{1}}$} \\
\hline Living with her & 4808 (89.7) & 2.4 & 1.0 \\
\hline Staying elsewhere & $553(10.3)$ & 5.6 & $2.5(1.7-3.8)$ \\
\hline \multicolumn{4}{|l|}{ Partner's education $\mathbf{b}$} \\
\hline No education & $1320(21.5)$ & 0.4 & 1.0 \\
\hline Incomplete primary & $1247(20.3)$ & 1.3 & $3.5(1.3-9.6)$ \\
\hline Complete primary & $2911(47.4)$ & 4.2 & $10.2(4.1-25.1)$ \\
\hline Secondary and above & $665(10.8)$ & 8.3 & $21.7(8.6-54.5)$ \\
\hline \multicolumn{4}{|l|}{ Sex of head of household } \\
\hline Male & $5548(79.0)$ & 3.3 & 1.0 \\
\hline Female & $1479(21.0)$ & 7.4 & $2.6(2.1-3.4)$ \\
\hline \multicolumn{4}{|c|}{ Using the following FP methods at time of survey } \\
\hline Not using any method & $5669(80.7)$ & 2.5 & 1.0 \\
\hline Folklore/traditional, methods & $343(4.9)$ & 5.2 & $2.3(1.4-3.8)$ \\
\hline Modern methods & $1015(14.4)$ & 12.8 & $6.4(5.0-8.3)$ \\
\hline \multicolumn{4}{|c|}{ AIDS KNOWLEDGE/AWARENESS } \\
\hline \multicolumn{4}{|c|}{ AIDS preventive measures spontaneously mentioned } \\
\hline None & $840(12.2)$ & 3.5 & 1.0 \\
\hline Condom use & $2875(42.0)$ & 7.6 & $2.3(1.5-3.4)$ \\
\hline Modify sexual behaviour $\mathbf{c}$ & $3628(51.6)$ & 4.7 & $1.5(1.0-2.2)$ \\
\hline Others $\mathbf{d}$ & $380(5.4)$ & 5.8 & $1.9(1.1-3.4)$ \\
\hline \multicolumn{4}{|c|}{ Does any member of your household has AIDS or died of AIDS? } \\
\hline No & $6256(91.4)$ & 4.0 & 1.0 \\
\hline Yes & $392(5.7)$ & 9.9 & $2.7(1.9-3.8)$ \\
\hline Don't know & $199(2.9)$ & 1.5 & $0.1(0.1-1.2)$ \\
\hline \multicolumn{4}{|l|}{ Have you ever tested for AIDS? } \\
\hline No & $6478(94.6)$ & 3.9 & 1.0 \\
\hline Yes & $330(4.8)$ & 10.6 & $2.9(2.0-4.2)$ \\
\hline Don't know & $40(0.6)$ & 5.0 & $1.6(0.4-6.9)$ \\
\hline \multicolumn{4}{|c|}{ SEXUAL BEHAVIOUR AND STDs } \\
\hline \multicolumn{4}{|c|}{ Reported sexual behaviour change since one became aware of AIDS } \\
\hline No change & $1408(20.6)$ & 1.3 & 1.0 \\
\hline Increased condom use $\mathbf{e}$ & $247(3.5)$ & 58.7 & $100.1(58.8-170.4)$ \\
\hline High-risk sexual behaviour $\mathbf{f}$ & & & \\
\hline No & $6483(92.3)$ & 2.9 & 1.0 \\
\hline Yes & $544(7.7)$ & 19.1 & $7.3(5.6-9.4)$ \\
\hline Have STD last 12 months & & & \\
\hline No & $5905(95.9)$ & 4.4 & 1.0 \\
\hline Yes & $162(2.6)$ & 9.3 & $2.2(1.3-3.9)$ \\
\hline
\end{tabular}

*Due to missing data, the numbers shown in each category may not add-up to the total numbers shown.

a For women who were married at the time of survey.

b Excludes women who had never married at the time of survey.

c Includes subjects who mentioned at least one of the following: abstain from sex, only one sex partner, avoid prostitutes, avoid homosexual sex, don't have many sexual partners.

d Includes subjects who mentioned avoiding blood transfusion or injections or alcohol.

e If said to have started or increased condom use.

f Women were classified to practice high-risk sexual behaviour if were married/cohabiting and had a regular partner or non-regular partner or if not married and had $>1$ regular partner or had a non-regular partner. 
Table 4

Predictors of condom use during the last sexual encounter among sexually active men $(N=1898)$, Tanzania Demographic and Health Survey, 1996

\begin{tabular}{|c|c|c|c|}
\hline & $\begin{array}{c}\text { No. }(\%) \text { in } \\
\text { each category* }\end{array}$ & $\begin{array}{l}\% \text { used condom } \\
\text { during last sexual } \\
\text { encounter }\end{array}$ & $\begin{array}{l}\text { Age-adjusted } \\
\text { OR }(95 \% \mathrm{Cl})\end{array}$ \\
\hline \multicolumn{4}{|c|}{ SOCIAL-DEMOGRAPHIC CHARACTERISTIC } \\
\hline \multicolumn{4}{|c|}{ Age (completed years) } \\
\hline $15-19$ & $216(11.4)$ & 17.1 & 1.0 \\
\hline $20-24$ & $318(16.8)$ & 28.0 & $1.9(1.2-2.9)$ \\
\hline $25-29$ & $286(15.1)$ & 21.7 & $1.3(0.9-2.1)$ \\
\hline $30-34$ & $261(13.8)$ & 16.5 & $1.0(0.6-\ddot{y} \ddot{y} X 1.6)$ \\
\hline $35-39$ & $244(12.9)$ & 13.5 & $0.8(0.5-1.3)$ \\
\hline $40-44$ & $214(11.3)$ & 5.6 & $0.3(0.2-0.6)$ \\
\hline$\geq 45$ & $359(18.9)$ & 3.3 & $0.2(0.1-0.3)$ \\
\hline$\overline{\mathrm{p}}$-value, test for trend & & & $<0.0001$ \\
\hline \multicolumn{4}{|l|}{ Education } \\
\hline No education & $256(13.5)$ & 5.5 & 1.0 \\
\hline Incomplete primary & $474(25.0)$ & 7.0 & $1.1(0.6-2.1)$ \\
\hline Complete primary & $947(49.9)$ & 19.1 & $2.6(1.5-4.7)$ \\
\hline Secondary and above & $221(11.6)$ & 27.1 & $4.8(2.6-9.0)$ \\
\hline $\mathrm{p}$-value, test for trend & & & $<0.0001$ \\
\hline \multicolumn{4}{|l|}{ Place of residence } \\
\hline Capital, large city & $243(12.8)$ & 33.3 & $3.3(2.4-4.6)$ \\
\hline Small city & $89(4.7)$ & 16.9 & $1.5(0.8-3.0)$ \\
\hline Town & $194(10.2)$ & 15.5 & $1.3(0.8-2.0)$ \\
\hline Rural areas & $1372(72.3)$ & 11.8 & 1.0 \\
\hline \multicolumn{4}{|l|}{ Marital status } \\
\hline Never married & $517(27.3)$ & 27.9 & $2.1(1.5-3.1)$ \\
\hline Married & $1151(60.7)$ & 9.3 & 1.0 \\
\hline Living together & $106(5.6)$ & 15.1 & $1.5(0.8-2.6)$ \\
\hline Widowed/divorced/separated & $122(6.4)$ & 17.2 & $1.7(1.0-2.9)$ \\
\hline \multicolumn{4}{|l|}{ Sex of head of household } \\
\hline Male & $1729(91.1)$ & 14.3 & 1.0 \\
\hline Female & $169(8.9)$ & 24.3 & $1.3(0.9-1.9)$ \\
\hline \multicolumn{4}{|l|}{ AIDS KNOWLEDGE/AWARENESS } \\
\hline \multicolumn{4}{|c|}{ AIDS preventive measures spontaneously mentioned } \\
\hline None & 177(9.4) & 7.3 & 1.0 \\
\hline condom use & $1079(57.0)$ & 21.7 & $3.1(1.7-5.6)$ \\
\hline Modify sexual behaviour $\mathbf{a}$ & $1195(63.0)$ & 15.5 & $2.3(0.8-4.2)$ \\
\hline Others b & $151(8.0)$ & 25.2 & $4.1(2.1-8.2)$ \\
\hline \multicolumn{4}{|c|}{ Does any member of your household has AIDS or died of AIDS? } \\
\hline No & $1758(93.2)$ & 14.9 & 1.0 \\
\hline Yes & $81(4.3)$ & 18.5 & $1.3(0.7-2.4)$ \\
\hline Don't know & $47(2.5)$ & 19.1 & $1.3(0.6-2.8)$ \\
\hline \multicolumn{4}{|l|}{ Have you ever tested for AIDS? } \\
\hline No & $1639(86.5)$ & 13.8 & 1.0 \\
\hline Yes & $255(13.5)$ & 24.7 & $2.3(1.6-3.2)$ \\
\hline \multicolumn{4}{|c|}{ SEXUAL BEHAVIOUR AND STDs } \\
\hline \multicolumn{4}{|c|}{ Reported sexual behaviour change since one became aware of AIDS } \\
\hline No change & $214(11.3)$ & 8.4 & 1.0 \\
\hline Increased condom use $\mathbf{c}$ & $307(16.2)$ & 58.6 & $12.9(7.5-22.2)$ \\
\hline \multicolumn{4}{|l|}{ High-risk sexual behaviourd } \\
\hline No & $1352(71.2)$ & 6.6 & 1.0 \\
\hline Yes & $546(28.8)$ & 36.4 & $6.9(5.2-9.2)$ \\
\hline \multicolumn{4}{|l|}{ Had STD during the last 12 months } \\
\hline No & $1667(91.3)$ & 14.9 & 1.0 \\
\hline Yes & $156(8.5)$ & 23.7 & $1.8(1.2-2.6)$ \\
\hline Don't know & $3(0.2)$ & 0.0 & - \\
\hline
\end{tabular}

*Due to missing data, the numbers shown in each category may not add up to the total numbers shown.

a Includes subjects who mentioned at least one of the following: abstain from sex, only one sex partner, avoid prostitutes, avoid homosexual sex, don't have many sexual partners.

b Includes subjects who mentioned at least one of the following: avoid blood transfusion, avoid injections, avoid alcohol.

c If said to have started or increased condom use.

d Men were classified to practice high-risk sexual behaviour if were married/cohabiting and had a regular partner or non-regular partner or if not married and had >1 regular partner or had a non-regular partner. 
Four hundred and thirty three men (22.8\%) and $1,000(14.3 \%)$ women had at least one regular sexual partner, while 405 (21.3\%) men and $365(5.2 \%)$ women had non-regular partners. High-risk sexual behaviour was much more common in men (28.8\%) than women (7.7\%). Among both men and women, respondents practising high-risk sexual behaviour were about seven times more likely to have used condoms. Among both women and men, perceived acceptability of condoms by their sexual partners was not a significant predictor of condom use (data not shown). Condom use was significantly increased in women and men who had contracted an STD in the past year.

In Table 5, we present the predictors of condom use from multivariate analyses. After adjusting for other significant predictors, condom use was inversely associated with age among women ( $\mathrm{p}$-value, test for linear trend $=0.009$ ). Among men aged below 40 was positively associated with age ( $\mathrm{p}$-value, test for linear trend $<0.0001$ ). In both men and women, condom use remained positively

Table 5

Predictors of condom use during the last sexual encounter in Tanzania - Multivariate results

\begin{tabular}{|c|c|c|}
\hline & $\begin{array}{l}\text { Women }(\mathrm{N}=7027) \\
\text { OR }(95 \% \mathrm{Cl})^{*}\end{array}$ & $\begin{array}{l}\operatorname{Men}(\mathrm{N}=1898) \\
\text { OR }(95 \% \mathrm{Cl})^{*}\end{array}$ \\
\hline \multicolumn{3}{|c|}{ SOCIO-DEMOGRAPHIC CHARACTERISTIC } \\
\hline \multicolumn{3}{|c|}{ Age (completed years) } \\
\hline $15-19$ & $3.7(1.9-7.0)$ & $1.1(0.5-2.5)$ \\
\hline $20-24$ & $2.2(1.2-4.1)$ & $1.9(0.9-3.8)$ \\
\hline $25-29$ & $1.6(0.9-3.1)$ & $2.2(1.2-4.3)$ \\
\hline $30-34$ & $1.2(0.6-2.3)$ & $2.7(1.4-5.2)$ \\
\hline $35-39$ & $1.1(0.5-2.2)$ & $2.3(1.1-4.4)$ \\
\hline$\geq 40$ & 1.0 & 1.0 \\
\hline $\mathrm{p}$-value, test for linear trend & 0009 & $<0.0001$ \\
\hline \multicolumn{3}{|l|}{ Education } \\
\hline No education & 1.0 & 1.0 \\
\hline Incomplete primary & $1.8(1.0-3.2)$ & $0.9(0.4-1.9)$ \\
\hline Complete primary & $2.0(1.2-3.4)$ & $1.5(0.8-2.9)$ \\
\hline Secondary and above & $2.5(1.3-5.0)$ & $2.3(1.1-4.9)$ \\
\hline $\mathrm{p}$-value, test for linear trend & 0.0001 & 0.08 \\
\hline \multicolumn{3}{|l|}{ Place of residence } \\
\hline Capital, large city & $1.8(1.2-2.8)$ & $2.0(1.3-3.1)$ \\
\hline Small city & $0.9(0.5-1.7)$ & $1.4(0.7-2.9)$ \\
\hline Town & $0.9(0.6-1.4)$ & $1.0(0.6-1.8)$ \\
\hline Rural areas & 1.0 & 1.0 \\
\hline \multicolumn{3}{|l|}{ Marital status } \\
\hline Married & - & 1.0 \\
\hline Living together & - & $0.6(03-1.3)$ \\
\hline Widowed/divorced/separated & - & $0.9(0.5-1.8)$ \\
\hline Never married & - & $1.9(1.1-3.2)$ \\
\hline \multicolumn{3}{|l|}{ Sex of head of household } \\
\hline Male & 1.0 & - \\
\hline Female & $1.6(1.2-2.2)$ & - \\
\hline \multicolumn{3}{|c|}{ Using the following family planning methods at time of survey } \\
\hline Never used & 1.0 & - \\
\hline Folklore/traditional methods & $1.6(0.7-3.2)$ & - \\
\hline Modern methods & $1.7(1.1-2.5)$ & - \\
\hline \multicolumn{3}{|l|}{ AIDS KNOWLEDGE/AWARENESS } \\
\hline \multicolumn{3}{|c|}{ Does any member of your household has AIDS or died of AIDS? } \\
\hline No & 1.0 & - \\
\hline Yes & $1.7(1.1-2.7)$ & - \\
\hline Don't know & $0.5(0.2-1.8)$ & - \\
\hline \multicolumn{3}{|l|}{ Ever tested for AIDS? } \\
\hline No & - & 1.0 \\
\hline Yes & - & $1.6(1.0-2.5)$ \\
\hline \multicolumn{3}{|l|}{ SEXUAL BEHAVIOUR AND STDs } \\
\hline \multicolumn{3}{|l|}{ High-risk sexual behaviour a } \\
\hline No & 1.0 & 1.0 \\
\hline Yes & $6.2(4.4-8.8)$ & $5.9(3.2-8.8)$ \\
\hline
\end{tabular}

*From logistic regression models that included all variables listed in this Table

a Subjects were classified to practice high-risk sexual behaviour if they were married/cohabiting and had a regular partner or non-regular partner or if not married and had $>1$ regular partner or had a non-regular partner. 
associated with level of education and was significantly increased among residents of capital or large cities. Similarly, condom use was significantly increased among respondents practising high risk sexual behaviours. In men, condom use remained significantly increased among never married and among those who had ever tested for AIDS. Among women, condom use remained significantly increased among women residing in households headed by women; in those using modern family planning methods; and in women who had a member of the household with AIDS.

\section{DISCUSSION}

In this study, we have examined the predictors of condom use in a large national representative sample of Tanzania. As observed in other sub-Saharan African countries (16-18), only a small proportion of men and women reported to have used condoms in Tanzania. Programmes to promote safer sexual practices and condom use are being implemented in many countries where the HIV/AIDS epidemic is rapidly expanding. In Tanzania, most HIV/AIDS control activities have focused on provision of information to raise HIV/AIDS awareness, reduction of high-risk sexual behaviour, and promotion of barrier methods such as condoms. With the formation of the Tanzania AIDS Project in 1993, these activities were expanded to include a significant involvement of indigenous non-governmental organizations, and social marketing of condoms to improve condom distribution and accessibility was initiated (19). Our findings in this report suggest that these activities have been less successful in increasing condom use in the general population of Tanzania.

We have identified the characteristics of people who are less likely to use condoms. This information helps to identify groups of people who might benefit from targeted intervention programmes designed to increase acceptability of condoms and promote safer sexual practices in Tanzania. Some of the groups that might be targeted by such programmes include women, young men, subjects with less formal education, residents of rural areas, and those in relatively stable sexual relationships. Experience from various countries shows that targeted HIV/AIDS programmes that address the specific barriers to condom use are more likely to induce behavioural changes than programmes that focus only on provision of information to raise awareness about HIV/AIDS prevention in the general population(20).

Although there is evidence indicating that the general awareness about HIV/AIDS is increasing in Tanzania $(13,14)$, we found knowledge about specific HIV/AIDS preventive measures in our study population was limited. For example, about $58 \%$ of women and $43 \%$ of men did not spontaneously mention condom use as HIV/AIDS preventive measure. Similarly, a substantial proportion of both men and women did not mention change of sexual behaviour as a strategy that can be used to lower their risk of HIV/AIDS. These findings indicate that additional efforts to increase knowledge about specific HIV/AIDS, preventive measures, including the role of condoms in HIV prevention, are urgently needed in Tanzania.

A substantial proportion of the study population reported multiple sexual partners, indicating that highrisk sexual behaviour was common in Tanzania. After adjusting for other predictors in multivariate analysis, respondents practising high-risk sexual behaviour were significantly more likely to have used condoms. Due to perceived HIV/AIDS protection, availability of condoms and willingness to use them may increase the tendency to engage in high-risk sexual behaviour (21). Others have hypothesized that increased condom use among people engaged in high-risk sexual behaviour might be indicative of some success in the efforts to promote condoms among people at highest risk of HIV/AIDS (22). However, most people reporting high-risk sexual behaviour did not use condoms, indicating that the majority of people with multiple sexual partners were not taking appropriate precautions to reduce their risk of HIV/AIDS. Hence, innovative strategies to promote safer sexual practices and condom use among people engaging in high-risk sexual practices needs to be developed and implemented in Tanzania.

After adjusting for other predictors in multivariate analysis, use of condoms during the last sexual encounter decreased with increasing age among women. However, we observed an opposite trend among men, condom use increasing with increasing age among men less than 40 years of age. Hence, more efforts are needed to promote condoms, and increase their acceptability among older women and younger men. Since the risk of HIV is higher among younger men and women, increased condom use in this age group is likely to contribute in reducing further spread of the HIV epidemic in Tanzania. As observed by other studies $(5,12)$, condom use increased with the increasing level of education and was significantly higher among residents of capital or large cities. In Tanzania, most HIV/AIDS control activities have been implemented in the large urban areas. Increased condom use in these areas might be due to a relatively high AIDS awareness, and improved condom availability and acceptability. Expansion of the existing condom promotion and distribution channels into the rural areas is required to increase availability of condoms in areas far removed from large urban centres.

Condom use within marriage was less common among both men and women. In most African countries, condom use within long-term sexual partnerships is often low because a suggestion to use condoms may be interpreted as a sign of lack of trust, being unfaithful, or engaging in "loose" behaviour (23). In addition, the desire for a large number of children may prevent most African women in long-term relationships to use condoms. Relatively increased use of condoms among unmarried women in less stable relationships might be due to several reasons. Women in less stable relationships may be motivated to 
use condoms because they perceive themselves to be at increased risk of HIV/AIDS (22). It is also possible that unmarried women are better positioned to negotiate condom use with their partners than women in relatively long-term relationships.

Women using modern contraceptive methods were more likely to have used condoms during their last sexual encounter. Since condoms are rarely used for contraceptive purposes in Tanzania (14), most of these women are likely to have used condoms for prevention of HIV and other STDs. Women who had a member of their household with AIDS or died of AIDS were more likely to have used condoms, indicating that personal knowledge of HIV/AIDS helps to motivate women to adopt safer sexual practices. We also observed increased condom use among men and women who had tested for HIV, although due to small numbers of condom users among women, this increase was no longer significant after we adjusted for other predictors in multivariate analyses. HIV counselling and testing has been shown to be associated with increased safer sexual practices and condom use in both developed and developing countries $(24,25)$. Given the existing demand for HIV testing in this population, expansion of the existing HIV counselling and testing services should be given the highest priority in Tanzania. Such services will help to increase the number of people who are aware of their HIV serostatus, and contribute in promoting safer sexual practices. HIV counselling and testing has been shown to be highly cost-effective intervention for HIV transmission, particularly when targeted to populations at high risk of HIV infection(26).

The findings of this study should be interpreted in the light of potential biases. Information about sexual behaviour is extremely sensitive and may be difficult to collect from study participants. Because of this, many authors have questioned the validity and reliability of information about sexual behaviour collected in surveys(27-29). As observed by other studies in Africa(12,17), we found much lower levels of multiple partnerships and condom use among women as compared to men. This may be due to under-reporting of non-marital sexual behaviour by women, or over-reporting by men, or due to real differences between men and women. However, we observed a very high level of consistency between some of the responses obtained at interview and selfreported sexual behaviour changes. For example, subjects who reported to have increased condom use after being aware of AIDS were more likely to have used condoms during their last sexual encounter. We also observed decreased reporting of high-risk sexual behaviour among respondents who reported to have changed their sexual behaviour in response to AIDS. These observations indicate that the information collected in this survey was reasonably valid and internally consistent.

In summary, we found a very low proportion of men and women in Tanzania reporting to have used condoms during their last sexual encounter. This suggests that the ongoing efforts to promote condom acceptability in Tanzania have been less successful. In this report, we have identified significant predictors of condom use among sexually active men and women. This information can be used to design programmes to increase condom use among people who are not taking appropriate precautions to reduce their risk of HIV/AIDS. Since promotion of safer sexual practices remains the central goal of HIV/AIDS prevention programmes, innovative approaches to increase condom use and acceptability are urgently needed in Tanzania.

\section{ACKNOWLEDGEMENTS}

The Bureau of Statistics in collaboration with the Tanzania Ministry of Health conducted the 1996 Tanzania Demographic and Health Survey (TDHS). Macro International Inc. through the DHS-III project supported this analysis. Core funds for the 1996 TDHS were provided by the USAID through the worldwide Demographic and Health Surveys programme. We thank Vanessa Bingham for editorial comments.

\section{REFERENCES}

1. Davis, K.R. and Weller, S.C. The effectiveness of condoms in reducing heterosexual transmission of HIV. Fam. Plann. Perspect. 1999; 31:272-279.

2. Heymann, D.L. and Edstrom K. Strategies for AIDS prevention and control in Sub-Saharan Africa. AIDS . 1991; 5(Suppl l):S197-S208

3. Rojanapithayakorn, W. and Hanenberg, R. The $100 \%$ condom program in Thailand. AIDS. 1996; 10:1-7.

4. Laga, M., Alary, M., Nzila, N. et al. Condom promotion, sexually transmitted diseases treatment, and declining incidence of HIV-1 infection in female Zairian sex workers. Lancet. 1994; 344:246-248.

5. Ngugi, E.N., Plummer, F.A., Simonsen, S.N.et al.Prevention of transmission of human immunodeficiency virus in Africa: effectiveness of condom promotion and health education among prostitutes. Lancet 1988; 2:887-890.

6. Centers for Disease Control and Prevention. Update: barrier protection against HIV infection and other sexually transmitted diseases. Morb. Mortal. Wkly. Rep. 1991; 42:589-591.

7. United Republic of Tanzania. National AIDS Control Programme: HIV/AIDS/STD Surveillance Report No. 13, Dar es Salaam, Tanzania, 1998.

8. Ng'weshemi, J.Z.L., Boerma, J.T., Pool, R. et al. Changes in male sexual behavior in response to the AIDS epidemic: evidence from a cohort study in urban Tanzania. AIDS. 1996; 10:1415-1420.

9. Kapiga, S.H., Lyamuya, E.F., Lwihula, G.K. and Hunter, D.J. The incidence of HIV infection among women using family planning methods in Dar es Salaam, Tanzania. AIDS . 1998; 12:75-84.

10. Bakari, M., Lyamuya, E., Mugusi, F. et al. The prevalence and incidence of HIV-1 infection and syphilis in a cohort of police officers in Dar es Salaam, Tanzania: a potential population for HIV vaccine trials. AIDS. 2000; 14:313-320.

11. Mnyika, K.S., Klepp, K.I., Kvale, G., Nilssen, S., Kissila, P.E. and Ole-King'ori, N. Prevalence of HIV-1 infection in urban, semi-urban and rural areas in Arusha region, Tanzania. AIDS. 1994; 8:1477-1481.

12. Kapiga, S.H. Determinants of multiple sexual partners and condom use among sexually active Tanzanians. East Afr. Med. J. 1996; 73:435-442. 
13. Ngallaba, S., Kapiga, S.H., Ruyobya, I. and Boerma, J.T. Tanzania Demographic and Health Survey. Bureau of Statistics, Planning Commission, Dar es Salaam, Tanzania and Macro International Inc., Columbia, MD, USA, June 1993.

14. Tanzania Bureau of Statistics and Macro International Inc. Tanzania Demographic and Health Survey 1996. Calverton, MD: Bureau of Statistics and Macro International Inc., 1997.

15. Hosmer, D.W. and Lemeshow, S. Applied logistic regression. New York: John Wiley \& Sons, Inc., 1989.

16. Lule, G.S. and Gruer, L.D. Sexual behavior and use of the condom among Ugandan students. AIDS Care. 1991; 3: 11-19.

17. Carael, M., Cleland, J. and Adeokun, L. Overview and selected findings of sexual behavior surveys. AIDS 199I; 5(Suppl 1):S65-S74.

18. Kamya, M., McFarland, W., Hudes, E.S. et al. Condom use with casual partners by men in Kampala, Uganda.AIDS 1997; 11(Suppl 1):S61-S66.

19. Tanzania AIDS Project midterm review report. Population Technical Assistance Project report No. 97-096-053, Arlington, VA, USA, 1997.

20. Over, M. and Piot, P. Human immunodeficiency virus infection and other sexually transmitted diseases in developing countries: public health importance and priorities for resource allocation. J. Infect. Dis. 1996; 74(Suppl 2):S162-S175.

21. Konde-Lule, J.K., Tumwesigye, M.N. and Lubanga, R.G.N. Trends in attitudes and behaviour relevant to AIDS in Ugandan community. East. Afr. Med. J. 1997; 74:406-410.
22. Kapiga, S.H., Lwihula, G.K., Shao, J.F. and Hunter, D.J. Predictors of AIDS knowledge, condom use and high-risk sexual behavior among women in Dar es Salaam, Tanzania. Int. J. STD AIDS. 1995; 6:175-183.

23. Pickering, H., Quigley, M., Hayes, R.J., Todd, J. and Wilkins, A. Determinants of condom use in 24000 prostitute/client contacts in The Gambia. AIDS. 1993; 7:1093-1098.

24. Weinhardt, L.S., Carey, M.P., Johnson, B.T. and Bickham, N.L. Effects of HIV counseling and resting on sexual risk behavior: A meta-analytic review of published research, 1995-1997. Am J. Public Health. 1999; 89:1397-1405.

25. Voluntary HIV-1 Counselling and Testing Efficacy study Group. Efficacy of voluntary HIV-1 counselling and testing in individuals and couples in Kenya, Tanzania, and Trinidad: a randomised trial. Lancet. 2000; 356:103-112.

26. Sweat M., Gregorich S., Sangiwa G., Furlonge C., Balmer D., Kamenga C., et al. Cost-effectiveness of voluntary HIV-1 counselling and testing in reducing sexual transmission of HIV-1 in Kenya and Tanzania. Lancet 2000; 356:113-121.

27. Catania, J.A., Gibson, D.R., Chitwood, D.D., and Coates, T.J Methodological problems in AIDS behavioral research: influences on measurement error and participation bias in studies of sexual behaviour. Psychol Bull. 1990; 108:339-362.

28. Dare, O.O. and Cleland, J. Reliability and validity of survey data on sexual behavior. Health Transition Review 1994; 4(Suppl 1):S93-S110.

29. Padian, N.S., Aral, S., Vranizan, K. and Bolan, G. Reliability of sexual histories in heterosexual couples. Sex Transm. Dis. 1995; 22:169-172.

\section{ERRATUM}

In our February Issue Volume 80 No. 2, pages 73-76, we erroneously ommitted the names of A.N Kiulia and $M$. De Beer on the list of authors after the title. We sincerely apologise for this error. 